\title{
Literary tourism: Opportunities and challenges for the marketing and branding of destinations?
}

\author{
Anne Hoppen a, Lorraine Browna,n, Alan Fyall b \\ a Bournemouth University, United Kingdom \\ b University of Central Florida, USA \\ a r t i c le in f o \\ a b s tract \\ This paper revisits the phenomenon of literary tourism and explores the means by which destinations \\ can leverage benefit in the form of destination branding and marketing strategies. The paper commences \\ with an overview of the typologies used to categorise the phenomenon and to outline the various forms \\ it takes in the particular geographic context of the UK. The extent to which literary tourism is a sub-set of \\ cultural and heritage tourism is then explored with the migration from niche to mass tourism \\ opportunity an emerging trend. With regard to literary places, the study identifies author-related, \\ fictional-related, book and festival related forms of literary tourism. Thereafter the study critiques further \\ the migration from niche to mass tourism, the move from cultural and heritage tourism to international \\ literary themed development, the collaborative development of literary destination products and \\ experiences, opportunities for destination brand development and finally broader policy and wider \\ local visitor management issues. The study concludes by advocating a collaborative approach to future \\ literary tourism development with collaboration needing to be consistent with the desired target \\ markets of each stakeholder, consistent with existing brands and perhaps most importantly, sustainable \\ in the longer term. \\ \& 2014 Elsevier Ltd. All rights reserved. \\ 1. Introduction \\ Literary tourism occurs when authors or their literature
}

become so popular that people are drawn to either those locations associated with the author (e.g. birthplace, home, graveside) or those featured within their writings (Busby \& Klug, 2001). Watson (2006, p. 3) notes that you 'may set eyes upon the very table on which Austen's Emma was written at Chawton', or 'may see the stone by the waterfall upon which Charlotte Brontë is said to have composed Jane Eyre, and on the same walk explore the path up the moorland valley to the place said to be the setting for her sister's Wuthering Heights'. Visiting such places allows literary enthusiasts to interact with the authors they admire insofar as they can see or touch objects or memorabilia associated with the authors (or their literature), an experience which is enhanced by the settings (Busby \& Klug, 2001). Literary pilgrims seek 'a physical body to enable their senses to connect with objects read' (Robertson \& Radford, 2009, p. 206). Nowadays, it is possible to visit a large range of literary tourism sites, ranging from places where 'your favourite author was born, grew up, courted, lived or died' over those where 'your favourite books were written', to those places 'where they are set' (Watson, 2006, p. 3).

At least in the UK, literary tourism has grown into a commercially significant phenomenon (Watson, 2006) and as a result of this, places connected to literature are frequently used to promote destinations, such as "Catherine Cookson County" in Northumberland (Herbert, 2001), "Shakespeare's Stratford", "the Brontes' Yorkshire", "Hardy'sWessex" (Squire, 1994), "Wordsworth's Lake District", "Scott-land" or "Dickens's London" (Watson, 2006). As Watson (2006, p. 5) notes: literary tourism has become so 'naturalised as a cultural phenomenon in the British Isles that one sees literary sites detailed in guidebooks and marked on the road map, and expects (and feels expected) to visit the museum shop and to buy the soap, the postcard and the bookmark'.

An indicator of the popularity of literary tourism in Britain and Ireland are the guidebooks on the topic, such as: "Blue Guide to Literary Britain and Ireland" (Ousby, 1999), "Literary Britain and Ireland: a guide to the places that inspired poets, playwrights and novelists" (Struthers \& Coe, 2005) and "The Oxford Guide to Literary Britain and Ireland" (Hahn \& Robins, 2008), which has been published in its third edition since 1977 and is probably the most popular and extensive guide of its kind. There also now appears to be a thriving industry for products related to literary places other than guidebooks, such as postcards, bookmarks, calendars, and other souvenirs, which can often be purchased in a literary destination. Numerous online shops have also emerged, such as "TheLiteraryGiftCompany.com", "WritersGifts.co.uk" or "BookishEngland. co.uk" - selling T-Shirts, handbags, soaps etc. related to authors and literature, to name only a few examples. There are also numerous websites dedicated to the topic, such as "LiteraryPlaces.com", "LiteraryTraveler.com" and "LiteraryTourist.com", which hosts a large searchable database of anything of interest to literary tourists, such as literary destinations, bookstores and related activities and events from all over the world. The website includes virtual literary maps and even a route planner, helping 
literary enthusiasts to put together a suitable travel agenda. The website also hosts a blog, "literarytourist.com/blog", featuring podcasts, interviews or literary criticism amongst others. Another example of a blog is "southeasternliterarytourisminitiative.blogspot. com", which is an organisation that actively promotes tourism through literature, such as short stories or poetry that feature real locations.

Even though literary tourism enjoys great popularity in Britain, it is not restricted to this geographic area. Furthermore, literary places are no longer just those ones connected with the authors of classical literature (Herbert, 2001) - a new generation of writers have appeared on the world's literary map, such as J.K. Rowling, Dan Brown or Stephenie Meyer. Mintel (2011) has put together some popular destinations linked to well-known authors (see Table 1). However, it needs to be pointed out that the table outlines 'some popular destinations linked to well-known literary personalities' (Mintel, 2011) and thus merely gives an overview. It could be interpreted in a way that indicates that literary tourism seems to occur more in Europe and North America. This suggestion could be undermined by the fact that most research around literary tourism has also clustered around those regions, such as, Herbert's (2001) study on Jane Austen/Chawton and Dylan Thomas/Laugharne (UK), Tetley and Bramwell's (2002) study on the Brontë sisters/Haworth (UK), Squire's (1994) study and Busby and George's (2004) research on Beatrix Potter tourism to Gloucester and the Lake District (UK), Squire's (1996) and Fawcett and McCormack's (2001) research on Lucy Maud Montgomery (author of Anne of Green Gables) tourism to Prince Edward Island (Canada), several authors (e.g. Banyai, 2010; Cosma, Pop, \& Negrusa, 2007; Muresan \& Smith, 1998; Reijnders, 2011) on Dracula tourism to Transylvania (Romania) and many, many more. Interestingly, there rarely seems to be any research on literary tourism in Asia. This does not, however, mean that literary tourism does not occur there. For example, according to Squire (1996), young Japanese women's interest in literary places in particular was leading to tourist travel, not domestically but to international destinations. For example, to Prince Edward Island, Canada, and the UK; both Lucy Maud Montgomery's Anne of Green Gables as well as the books by Beatrix Potter appear to be very popular in Japan (Squire, 1994, 1996). One Asian example of academic research into literary tourism originates from South Korea, where the home village of popular novelist Kim Yujeong (1908-1937), which was at the same time the setting for his novels, has officially been named "Literary Village of Kim Yujeong" (Lee \& Weaver, 2012) and offers an exhibition hall, a walking path and a hiking trail (VisitKorea, 2013).

The assumption that literary tourism in its different forms, which will be discussed in detail later, tends to be more of a European and North American phenomenon could also be supported by the UNESCOs creative cities network, which is an innovative way for cities to highlight their cultural assets and thus widen their tourism offerings (UNESCO, 2013). UNESCO has so far appointed seven cities (which had to go through an application process in order to be appointed) as UNESCO Cities of Literature: Edinburgh, Melbourne, Iowa City, Dublin, Reykjavik, Norwich and Krakow, all of which are European or North American, which could be interpreted as an indicator that European and North American DMOs or other private or public sector agencies are actively trying to promote literary tourism.

Literary tourism is also beginning to find its way into the virtual world of the internet and mobile phone applications. An example of the latter is "Ian Rankin's Edinburgh", a free app commissioned by the author's publisher that serves as a virtual guided tour of Edinburgh and gives background information on key locations to the stories and its characters (Orion Publishing Group, 2011). Furthermore, there are virtual literary maps, such as the one developed by The Edinburgh UNESCO City of Literature Trust (2013) amongst many others, which shows writers' homes and haunts as well as monuments and other places of interested related to literature. The example of Ian Rankin in Edinburgh is an interesting case in point as it reflects a trend toward "living" literary tourism in that the author himself is actively engaged in promoting and implementing the literary tourism product (see for example http://www.theguardian.com/travel/2009/oct/ 25/travel-awards-edinburgh-ian-rankin; http://www.rebustours, 
com/; http://www.undiscoveredscotland.co.uk/edinburgh/rebus/). Literary places attract both general heritage visitors as well as a niche segment of genuine literary pilgrims (Smith, 2003), whom Herbert (2001, p. 313) characterises as well-educated tourists, 'versed in the classics and with the cultural capital to appreciate and understand this form of heritage'. Despite literary tourism being considered a niche, it is of growing relevance within the field of cultural and heritage tourism. The demand for cultural holidays increased by 17\% between 1997 and 2007 (Mintel, 2010) while the OECD and UNWTO (see Mintel, 2010) reported that cultural tourism accounted for $40 \%$ of all international tourism in 2007. Unfortunately, there remains no statistical data available on the scale or market size of literary tourism.

Notwithstanding the growth and potential of the literary tourism, market research on the subject has been relatively limited in comparison to studies on film tourism. That said, studies on literary tourism within the last three decades include work by Squire (1994, 1996), Herbert (2001), Busby and Hambly (2000), Busby and Klug (2001), Busby and George (2004), Busby (2004) with earlier studies by Pocock (1982) and Butler (1986) frequently cited. In the last two decades two relevant books on the topic have emerged: "Literature and Tourism - Reading and Writing Tourism Texts" (Anderson \& Robinson, 2002) and "The Literary Tourist" (Watson, 2006). Furthermore, the Centre for Tourism and Cultural Change's 2004 international research conference was themed

"Tourism \& Literature: Travel, Imagination \& Myth" and had as its aim to critically discuss the interrelationships between tourism, tourists and literature (Robinson \& Picard, 2004). In addition, the market research company Mintel published in September 2011 their first ever report on literary tourism.

In view of the above, the aim of this paper is to define literary tourism, to outline the various forms it takes and to suggest ways in which destinations can and should capitalise on the potential market for literary tourism. This paper focuses on the branding and marketing of literary tourism sites in the UK.

\section{Defining literary tourism}

Literary tourism or tourism associated with 'places celebrated for literary depictions and/or connections with literary figures' (Squire, 1996, p. 119), forms part of the landscape of heritage tourism (Herbert, 2001). According to Andersen and Robinson (2002, p.viii), it goes back several centuries, at least to the Roman Empire with them categorising literary tourism as cultural tourism in the anthropological sense, 'in that it involves tourists and visitors identifying with, discovering, and creating signifiers of cultural values with those people who have become part of the cultural mythologies of places'. Squire $(1994,1996)$ and Herbert (2001), meanwhile, categorise literary tourism as heritage tourism, which raises the question: what differentiates cultural and heritage tourism? According to the National Trust for Historic Preservation (2011), the two cannot be defined as two entirely

different forms of tourism, as they partly overlap. The main

difference is that heritage tourism is more "place-based" in that it creates a sense of place embedded in the local landscape, architecture, people, artefacts, traditions and stories that make a place unique, while cultural tourism is broadly concerned with the same types of experiences as heritage tourism, but at the same time less concerned with place. Thus viewing the work of an artist in their home or studio is categorised as a heritage tourism experience whilst viewing their art as part of an exhibition away from the artist's place of residence or working is cast as a cultural tourism experience.

Based on the above, Squire and Herbert's classification of literary tourism as heritage tourism is supported in this paper, as place plays a particularly important role in literary tourism. However, bearing in mind Andersen and Robinson's (2002) earlier remarks about visitors who identify themselves with those who have become part of the cultural mythologies of places, which is also a vital part of literary tourism, cultural tourism cannot be dismissed as a main category. Therefore, and based on the fact that there seem to be as many different definitions of cultural tourism as there are cultural tourists, this paper supports the combination of the two terms cultural and heritage tourism, as elements of both types of tourism are relevant for literary tourism and since the heritage visitor and the cultural visitor are likely to be similar (National Trust for Historic Preservation, 2011). Furthermore, 
according to VisitBritain (2010) it is just as difficult for consumers to separate culture and heritage themselves, which supports the proposition to categorise it as "Cultural and Heritage Tourism". It must be acknowledged that other definitions have been proposed, for example, Busby and Klug (2001, p. 316), consider literary tourism to be part of media-related tourism, which they define as tourism involving 'visits to places celebrated for Table 2

Forms of literary tourism.

Source: adapted from Busby (2004, p. 5) and Busby and Klug (2001 p. 321). Form Description

Butler's original forms of literary tourism 1. Aspects of homage to an actual location

To see the background against which a work was produced to gain new insights into the work and the author. This form involves the enter the literary pilgrim (Butler, 1986) the literary pilgrim (Butler, 1986)
2. Places of significance in the work of fiction

The novel 'Tarka the Otter' by Henry

Williamson brought tourists to the

rural part of North Devon, where it

was set (Wreyford 1996)

3. Appeal of areas because they were

appealing to literary and other

figures

The form of tourism which is

connected with literary figures (Squire

1996). Widely used by the private and

public sector to promote areas and to

gain economic benefit.

4. The literature gains popularity in a

sense that the area becomes a

tourist destination in its own right

This form is illustrated by Charles

Kingsley's Westward Ho! which

resulted in the creation of the

eponymously-named seaside resort in

North Devon (Busby and Hambly

2000).

Busby and Klug's added forms

5. Travel writing A vehicle through which places and

people have been re-interpreted and

communicated to wider audiences

consus by the work of Bill Bryson.

6. Film-induced literary tourism Tourism resulting from enhanced

interest in a destination, secured

through reading the literature after

viewing the screenplay.

Table 3

The 10 most influential fictional characters in world

literature and legend.

Source: adapted from Pollard-Gott (2009).

Rank Literary figure

1 Hamlet

2 Odysseus

3 Don Quixote

4 Eve

5 Genji

6 Oedipus

7 Don Juan

8 Chia Pao-yü

9 Sherlock Holmes

10 Arjuna

associations with books, authors, television programmes and films'. Meanwhile the term creative tourism is put forward by Mintel (2011), which is defined as tourism that embraces the creative arts, such as design, architecture, music, film, media, music and literature. Literary tourism can thus be considered as a niche (media-related tourism) within a niche (creative tourism) in the wider field of cultural and heritage tourism (see Fig. 1).

3. Types of literary tourism

In Butler's (1986) typology of literary tourism, four types of literary tourism are identified. These are supported and extended by Busby and Klug (2001) who added two further types (see Table 2). The first type of literary tourism cited is homage to an actual location: Busby and Hambly (2000) give the example of Daphne du Maurier's “Jamaica Inn”, an old coaching house on Bodmin Moor in the UK that inspired Du Maurier's homonymous novel.

This form of literary tourism refers to a mixture of both fictionrelated literary tourism and author-related literary tourism, as, even though it refers to an actual location, it is also about the author's connection to that particular location. Watson (2006) notes that the literary tourist's experience is likely to be most 
powerfully compounded when both the place of composition and that of the fictional setting coincide. This is the case for $\mathrm{Du}$ Maurier, at least for a number of her novels. Fowey (Cornwall) is connected with the author in several ways: first of all, it was her family's holiday residence where she wrote her first novel "The Loving Spirit" in 1931, which has romanticised Fowey and its surroundings and created what was to become a life-long association with the county in her fiction (Busby, 2004). Furthermore, the author decided to move to Fowey permanently in 1943, where she lived until her death in 1989 (VisitCornwall, 2011). The area inspired many of her books, and the house she lived in for many years. For example, there is a "Daphne du Maurier in Cornwall" guide for sale in the tourist information centre/Daphne du Maurier Literary Centre. This claims to include all there is to know about du Maurier while visiting Cornwall and to take tourists to the heart of du Maurier's world (Creative Media Publishing, 2011); it also features maps and background information on the author and places connected with her and/or her books. Busby (2004) argues that this "sense of place" in her Cornish novels adds an element of "hyper reality" to the region, which benefits the development and marketing of "Daphne du Maurier Country" and the annual "Daphne du Maurier Festival of Arts and Literature".

Butler's (1986) second form of literary tourism refers to fictionrelated literary tourism, as it is concerned merely with places of significance within the work of fiction (Busby, 2004) and thus is less focused on the author. An example is the description of North Devon (in the UK) in Henry Williamson's novel "Tarka": a 180 mile long walking route is a popular visitor attraction (ibid).

The third form of literary tourism is concerned with the appeal of areas because they were appealing to literary (and other) figures. According to Busby (2004), this is a more specialist form of literary tourism, which nonetheless is widely used by the private and public sector to promote areas in order to gain economic benefits (Busby \& Klug, 2001). In this category Busby places guidebooks such as Margaret Drabble's (1984) "A Writer's Britain: Landscape and Literature" or Bradbury's (1996) "The Atlas of Literature", a compendium of over 450 literary figures worldwide. The last form as put forward by Butler (1986) applies when an area becomes a tourist destination in its own right based on the popularity of an author. Busby (2004) cites the example of

"Westward Ho!" in North Devon, a sea-side town in the UK which was developed and named after Charles Kingsley's novel of the same title (published in 1855). The book's popularity initiated such interest in this area near Bideford that a group of entrepreneurs, chaired by Lord Portsmouth, decided to establish a health resort there in 1863, which, however, turned out to be only moderately successful (Devon History Society, 2010).

Busby (2004) furthermore argues that this fourth form of

literary tourism also applies when an area becomes a "country", such as "Hardy Country", "Catherine Cookson Country" or "Agatha Christie Country". The latter, Agatha Christie Country, has been the subject of a study on resident perceptions of literary and filminduced tourism by Busby, Brunt, and Lund (2003), which was

unfortunately unable to identify its effects on residents, as no data on visitor numbers was available: it was not possible to measure

HERITAGE TOURIS: M
sense of place rooted

in the local landscape

architecture, people,

artefacts, traditions

and stories

CULTURAL TOURISM

visitors identifying

with, discovering, and

creating signifiers of

cultural values with

those people who

have become part of

the cultural

mythologies of places

Tourism

Embracing

Creative Arts:

design,

architecture,

music, film,

literature

Literary Tourism

Visits to places celebrated for

associations with books \&

authors 
films

Fig. 1. Classification of Literary Tourism within the Field of Cultural and Heritage Tourism. the number of visitors who had been motivated by films or

literature.

The fifth and sixth form of literary tourism as put forward by Busby and Klug (2001) are "travel writing" and "film-induced literary tourism". Travel writing, in those cases where it is an influential factor in tourism and destination decision-making, is considered a channel through which both places as well as people have been re-interpreted and communicated to wider audiences. An example of this would be Bill Bryson's humorous travel writings, such as his international breakthrough, "Notes from a Small Island" which has been voted the book that best represents Britain. Further examples include "A Walk in The Woods" on Bryson's journey on the longest continuous footpath in the world along the U.S. East coast and "Down Under" (Random House, 2013). According to Goodreads.com (2013), "every time Bill Bryson walks out the door, memorable travel literature threatens to break out" and indeed, his books are bestsellers (ibid). However, even though it is likely that his travel books may have prompted tourism visits, there is no data available on this.

"Film-induced literary tourism" is based on film-induced tourism, whereby a tourist has read an author's work after having viewed the film based on the work. Even though many films and television dramas are in fact based on literature, in this particular case of literary tourism the book is 'only a souvenir, providing a permanent reminder of having seen the film' (Busby, 2004, p. 4). Therefore, film also serves as a medium that re-popularises literary works and destinations and can make literature more attractive to mass audiences. Or in other words, 'film is to literary tourism what the Boeing 747 was to mainstream tourism - a major booster for mass tourism' (Beeton, 2005, p. 53). One example of literature turning film tourism into mass tourism is the Lord of the Rings: one per cent of all visitors to New Zealand in 2004 stated the Lord of the Rings as their main or only reason for visiting the country, while six per cent said it was one of the main reasons (Tourism New Zealand, 2013).

It can be argued that this sixth form of literary tourism is a case of fiction-related literary tourism, even though it could be questioned whether a film-induced tourist has quite the same motivations to visit a location featured on TV as one solely motivated by literature. The experiences may well be equally powerful, but the tourist solely motivated by works of fiction may have a different, deeper appreciation and understanding of the actual literature than the one who only watched a film-adaptation of a book. This thesis is supported by Busby and O'Neill's (2006) study on the influence of literature and film on British visitors to the island of Cephallonia (the novel, "Captain Corelli's Mandolin" appeared in 1994 whilst the film of the same title was released in 2001). It found that tourists who had visited Cephallonia because of the book preferred unchanged or less promotion, while those who were visiting because of the film were looking for more promotion. This leads to the assumption that literary tourists may prefer to "layer their own meanings onto a site" (Busby \& O'Neill, 2006, p. 102) as opposed to film-induced tourists, who seem to be looking for more, such as film-related products or experiences.

4. Literary places

The wider literature identifies two broad types of literary places: real-life places associated with the lives of writers (e.g. birthplaces, chosen domiciles, gravesides), and imagined places, associated with written works (e.g. Anderson \& Robinson, 2002; Herbert, 2001; Squire, 1996; Watson, 2006). In addition, Mintel (2011) advance two other forms that literary tourism can take in their recent market research report, namely literary festivals and bookshop tourism.

4.1. Author-related literary tourism

Visiting poets' graves is a practice dating from classical antiquity which gained increased interest in the mid-eighteenth

century along with growing interest in "necro-tourism", i.e. the practice of visiting graves/graveyards in general (Watson, 2006). Watson (2006, p. 33) argues that this literary pilgrimage is premised on religious pilgrimage, a practice that has declined along with decreasing religious sensibility to a certain extent, thus, 
that 'the saint and his or her holy and healing places' were replaced by 'the author and his or her native haunts'. In this context, it can however be argued that the desire to visit the mortal remains of a saint and those of a writer are likely to be different, as Dávidházi (1998, cited inWatson, 2006) puts it: 'What miracle, after all, were the mortal remains of a writer supposed to perform that their living books had not?'. Nonetheless, writers' graves and memorials can be considered as tangible signatures of a writer's presence and sometimes allow literary pilgrims to come as close to an admired author as they would ever get (Andersen \& Robinson, 2002).

Writers' birthplaces are of course in one sense the houses of writers - they are, however, rarely the houses in which the written works have been created, with few exceptions such as Thomas Hardy's cottage in Upper Bockhampton (Watson, 2006). Furthermore, according to Watson (2006), it is one thing to pay one's respects to the human remains of a poet or writer, but another thing to actually make a pilgrimage to the place where the poet or author was born. She explains the difference between the two through the author's physical existence, proof of which - outside of the written works - is provided by the grave. However, in order to turn a birthplace into a similar memorial requires much more effort of one's imagination, which is why the extension of emotional investment from an author's grave to his or her birthplace only manifests itself for relatively few authors, such as for example Shakespeare, whose birthplace (at Stratford upon Avon) has been transformed into a visitor attraction (Watson, 2006).

According to Herbert (2001), people may be drawn to former homes of writers due to a sense of nostalgia. The preserved home of the dead writer offers the promise of him or her to re-enter the home at any point (Andersen \& Robinson 2002), thus, viewing the house of the author can be considered as an imaginative act to bring the dead author back to life once more (Watson, 2006). One's creative imagination contributes to the illusion of the creative, but dead, author being just as present as are his or her books (Andersen \& Robinson, 2002). Furthermore, Anderson and Robinson (2002) note that a writer's home is probably one of the most powerful tourism resources as it provides tangible connections between the "created" and the "creator", which allows visitors to engage in diverse emotional experiences. It furthermore offers a real sense of "behind the scenes", as it is an intimate and authentic experience to be able to be where the author's pen physically touched the paper. Not only is the writer's home the place where he or she lived, but the "creative space" where the writer's works were conceived and realised (Smith, 2003). Moreover, the place that an author chooses to live in, other than a birthplace, can be interpreted as a reflection of his/her interests and desires and of a way to express himself/herself (Smith, 2003). This brings rise to the question why it is so popular, as Booth (2004, p.2) puts it: 'What incites the reader to become the uninvited, posthumous guest, to wish to sit in the author's chair or meditate upon the views out the poet's window?' 4.2. Fiction-related literary tourism

Herbert (2001) notes that real characters and places as well as fictional characters and places are sometimes linked insofar that places can acquire meanings from imaginative worlds, which, however, are real to the beholder in that they evoke emotions and involvement. According to Eco (1986), tourists seek - what he calls - "hyper real" destinations, where there exists a link between fictional or mythical characters and their supposed actions in real locations, such as Robin Hood and Sherwood Forest. The "reality" of real locations within the works of fiction can, of course, be questioned, and Andersen and Robinson (2002) rightly ask whether it is sensible to visit a real location merely for the reason that it was featured within a narrative plot. Herbert (2001), however, argues that places like that, where the real and the imagined merge, possess special meaning to visitors. Pocock (1987, cited in Busby \& Hambly 2000, p. 204) noted that 'the thought that Heathcliff might appear' evoked more excitement in visitors to Haworth than being able to tread in the footsteps of the Brontë sisters. In our apparent willingness to take fictional characters seriously, some of those characters - despite being narrative - are considered "influential" (Andersen \& Robinson, 2002). There is even a list of the 100 most influential fictional characters in world literature and legend, with Shakespeare's Hamlet at the top of that 
chart, Arthur Conan Doyle's Sherlock Holmes in ninth place and Jane Austen's Emma in seventieth place (see Table 3). The top 10 of that list also include Asian characters, such as Genji, who is said to have influenced Japan for 1000 years, Chia Pao-yü, the hero of a Chinese novel dating back to 1792 as well as Arjuna, the hero of India's national epic (Pollard-Gott, 2009).

Furthermore, locations featured in the literature can ignite 'an appreciation and understanding of literature as means of reflection and self-reflection' (Andersen \& Robinson, 2002, p. 2), and at the same time serve as portals to infinite realities: 'we read, and by sharing the author's insight and understanding of the real world, our insight and understanding is also broadened'.

"Place" plays an important role for literary tourism, in particular for fiction-related literary tourism. Writers can define and redefine spaces through their works (Andersen \& Robinson, 2002) and literature has the ability to reflect real space and its use (Andersen and Robinson 2002). They go on to point out that the relationship between experiences in real time and place and created places is multifaceted. One reason for this can be considered the fact that the author's use of real places within his or her fiction is usually laden with sets of interpretations from both the author as well as the reader (Robinson, 2002). To some authors' work, "place" is central in that they set out to represent the latter, to capture the spirit of place or even to create myths about places (Barke, 2002). Furthermore, an author's own experience of place/places is the most obvious foundation for the development of creative writing (Robinson, 2002). Therefore, Tetley and Bramwell (2002) argue that it is the authors who form what they refer to as "place myths", which convert into symbolic imageries and meanings shared by many readers. Watson and Saunders (2004), conversely, argue that it is the reader who interprets the author's written words into their own vision of reality, and therefore it is also the reader who actually produces the place, not the writer. It can be argued that both arguments bear truth, as creative fiction cannot exist in isolation from the real world (Robinson, 2002). It may be the writers who have transformed their vision and the context of their visions into words (Watson \& Saunders, 2004), but it is the reader's own culture and knowledge which enhance their understanding of place, and it is readers who are 'allowed to cruise the real world within their imagination and to fuel their imagination through glimpses, representations and deliberate distortions of realities' (Andersen \& Robinson, 2002 p. 21).

As the reader develops a relationship with the context of the characters during the course of reading, his or her sense of place becomes more real (Watson \& Saunders 2004). According to Watson and Saunders (2004), the reader, who is an outsider whilst reading, yearns to capture the non-existent by travelling to the real place featured within fictional works. This hazy boundary between fiction and reality is fundamental to the decision-making regarding visiting a destination represented within fiction (Andersen \& Robinson, 2002). The reader has expectations that can only be satisfied by the sense and quality of place and tourists who visit fiction-related literary places do so to enlighten and/or to either confirm or change this "sense of place" (Watson \& Saunders, 2004). Hudson and Ritchie (2006, p.395) propose to market destinations through "product placement" in films and television shows, where the destination represents the product. This is considered an attractive marketing vehicle which 'increases awareness, enhances destination image, and results in significant increases in tourism numbers, succeeding where traditional marketing efforts cannot'. Even though film-induced tourism differs from literary tourism, this proposed marketing vehicle could possibly be adapted to literary tourism, where authors may actively promote a particular destination through their fiction. This way, a particular destination could be favourably differentiated from competing destinations as well as being "positively positioned" in the minds of consumers, which could influence tourist behaviour (Echtner \& Ritchie, 2003; Hudson \& Ritchie, 2006; Pike \& Ryan, 2004). However, it is arguably more challenging to solicit authors to promote destinations than a film director.

4.3. Literary festivals

There are a vast number of yearly literary festivals of different scales taking place in every corner of the UK. Those festivals normally allow attendees some personal interaction with authors, entertainers and/or celebrities as well as giving writers the chance 
to promote their readings (Mintel, 2011). In that context, Anderson and Robinson (2002, p. 9) note that 'we now expect them [authors] to appear in person, to present and explain their work, to allow us to hear the voice and see the person behind the work'. According to Mintel (2011), the emphasis at literary festivals was once on serious literature, but has widened considerably and nowadays includes other related events - usually from the wider field of arts - such as films, TV documentaries, audio books etc., as those are part of contemporary culture. In this context, Seaton (1999) notes the important role of what he calls "book towns" in rural tourism, referring to the example of Hay on Wye, which is acknowledged as a centre for bookshops and hosts the yearly "Hay Festival of Literature and the Arts". As noted above (Herbert, 2001, p. 313) suggests that 'literary places are no longer accidents of history, sites of a writer's birth or death; they are also social constructions, created, amplified, and promoted to attract visitors', which can be achieved by the creation of a literary festival. 4.4. Bookshop tourism

Mintel (2011, p. 34) defines bookshop tourists as 'people who, when they travel, trail around local bookshops to seek out titles related to the destination they are visiting (guide books, literary maps, literary tours etc.) or to search for books written by local authors'. Despite the pressure that bookshop chains have been under from large online retailers and although e-books have been outselling their print books in recent years (Investopedia, 2013), it is unlikely that this is going to affect bookshop tourism to the same extent. This is because bookshop tourism tends to be the domain of independent, often small book retailers, which might specialise in certain literature genres; they at the same time tend to have an online-presence in order to compete with large book chains (Mintel, 2011). The demand for this type of small speciality book shop offering quality literary publications, rare or antiquarian books, is increasing according to Nigel Beale, who publishes the website LiteraryTourist.com. This also indicates the status of books as a collector's item with a 'life well beyond the one they enjoy when they are new in the market' (Andersen \& Robinson, 2002, p.14). Therefore, even though e-books have overtaken their print opponents, the book as the physical form of literary works still has remarkable power and can be considered cultural capital in their objectified state (Bourdieu, 1986). After all, permanent or temporary possession of literature forms the basis of literary culture and is considered a well-established practice across western democracies (Andersen \& Robinson, 2002).

5. Literary destinations and their marketing Herbert (2001) proposed a distinction between exceptional and general qualities of literary places, based on the reasons why people are drawn to those places. A literary place has exceptional qualities when tourists are drawn to places with connections with the lives of writers, to literary places that form the settings for novels, to literary places for some broader and deeper emotion than the specific writer or the story (e.g. nostalgia) or for reasons less concerned with the literature than with some dramatic event in the writer's life (Herbert 2001). In addition to those exceptional qualities, literary places can have more general qualities which can be used to promote their attractiveness. Those apply when literary places: are located in attractive settings, such as scenic environments; offer a range of facilities (afternoon teas, souvenirs); and become stopping points along a more general tourism itinerary because of their geographically convenient location (e.g. locations that fit into a route along cathedrals, churches, country houses and gardens). As a place marketing tool, such sites of interest can also be linked through the development of literary heritage trails, which provide a purposeful and interpreted route for visitors to follow on foot, by car, by bike or even on horseback (MacLeod, Hayes, \& Slater, 2009). Connecting such sites, according to Andersen \& Robinson, (2002, p. 22), creates 'a more potent and penetrative tourist product, not just in promotional terms but in a wider intellectual sense, too'.

It can be argued that the more exceptional qualities a literary place possesses, the easier it is to develop and exploit for tourism purposes. When the place of composition and that of the fictional setting coincide, the literary tourists' experience is more powerfully compounded (Watson, 2006), therefore it is likely that this is also the case when other qualities apply to the place, such as the setting or its facilities. 
The question of authenticity, however, ought to be kept in mind by those developing a site for tourism. When tourists see places linked to literature, they do so in a comprehensive way in their search for cultural and literary authenticity, that is, they want the reality of the place as they imagined it (Watson \& Saunders, 2004). Questions of authenticity - that is, are the places genuine and do they faithfully represent reality? - are commonly asked with regards to literary places (Herbert, 2001). According to Herbert

(1995, p. 34), one issue regarding authenticity in literary tourism is linked to the fact that 'lines blur as imagined worlds vie with reallife experience'. Furthermore, authenticity is considered to be socially constructed (Herbert, 2001), that is, it has been produced by various entrepreneurs, marketing agents, interpretative guides, animators, or institutional mediators (Hughes, 1995). This brings rise to the question whether there is such a thing as authenticity in literary tourism at all? Fawcett and McCormack (2001, p. 64) argue there is not, as 'authenticity can no longer exist in the sense of the "real" or "original" thing standing outside of cultural interpretation', and conclude that "mass-produced images of touristic objects and experiences always pre-exist the "real"'. But do tourists mind? Herbert (2001) argues that authenticity becomes a subjective experience in the case of developing a literary place for tourism purposes in that it is a combination of the developers' intentions and the consumers' interpretations of the latter.

A literary place's existing exceptional and general qualities can arguably form the basis of the particular place's image, which can be exploited for marketing purposes. As Brito (2004) argues, tourism converts the places portrayed in literature into a consumption product. An increasing number of private and public sector agencies in the UK have realized the potential of literary tourism and are promoting specific images of those places (Herbert, 1995). Examples of such successful literary place marketing include places as "Shakespeare's Stratford", "the Brontës' Yorkshire", "Hardy's Wessex" (Squire, 1994), "Wordsworth's Lake District" or "Dickens' London" (Watson, 2006). Despite this success, there remains scope for many other destinations to seek their own opportunities from local authors or from sites closely associated with literary works. As such, the section that follows provides a synthesis of six distinct but inter-related marketing and branding strategies that destinations with literary heritage (or ambition) are encouraged to consider as a means of developing their destinations and thereby gaining maximum benefit from their historical or current literary connections.

6. Future literary destination marketing and branding strategies

6.1. From niche to mass tourism

Perhaps the most significant shift in recent years in the domain of literary tourism has been the migration from niche to mass tourism opportunities with literary festivals now expanding their scale and reach in many countries around the world. The Hay Festival, which takes place annually in Wales, recorded 225,000 ticket sales, 11.8 million tweets and 72,000 books sold in 2012 and represents just one example of the expanding appeal, and future potential, of literary tourism (Hay Festival, 2012). The mass appeal of literature is perhaps best personified in recent years by the global success of the literary figure Harry Potter. Along with Downton Abbey, Harry Potter has played a significant role in contributing to one-in-three UK tourists visiting a historic house in 2013 with the economic spend of such visits estimated at d6.5 billion. More locally, visitors to Alnwick Castle in Northumberland in northern England, which served as Hogwarts in the first two Harry Potter films, jumped 230\% between 2011 and 2013 with an estimated economic contribution of $\mathrm{d} 9$ million to the local economy (Daily Mail, 2013). Bloomsbury's revenue levels, the publisher of the Harry Potter books, jumped ten-fold after the launch of the books with more than 400 million books sold worldwide and cinema ticket sales exceeding \$5.4 billion (Economist, 2009). Müller (2006, p.214) touched on this emerging phenomenon when he questioned the extent to which literary places still represent 'exclusive places for those seeking enrichment by experiencing the settings of the authors' works or working environments' or whether they have broadened out to meet the needs of modern tourism and the demands of destinations eager to establish differential advantage in the marketplace (see also Herbert, 1996; Philips, 1999). Hence, whereas only a few years 
back, The Elephant House in Edinburgh, where J.K. Rowling authored the initial chapters of the early editions of Harry Potter, would perhaps have been one of only a few opportunities for destinations to leverage tourism benefit from literary figures, more recent developments at London's Kings Cross station and the development of "The Wizarding World of Harry Potter" at Universal's Islands of Adventure theme park in Orlando, Florida, have clearly been developed for the masses. Although purists may argue that the latter represents the commodification of literature for the masses via the provision of passive experiences, there can be little doubt that J.K. Rowling's iconic character has changed the landscape, dynamics and marketing and branding potential of literary tourism for destinations around the world (Gunelius, 2008). Harry Potter is not alone with his influence on theme parks as evidenced by Parc Asterix near to Paris, Dickens World in England and The Holy Land experience in Orlando, Florida. It is interesting to note that the Opening Ceremony of the London 2012 Olympic Games was awash with Britain's rich literary heritage, most notably children's literature, with the likes of Mary Poppins and Peter Pan, to name but a few, contributing much to the imagery of Britain projected around the world (Graham et al., 2013). That said, however, that there was no space for Harry Potter!

In her study of film tourism in Tobermory on the island of Mull in Scotland, one of Connell's (2005) key findings was that irrespective of the actions of destinations, visitors were going to come anyway. As evidenced in her study, despite any significant promotional activity tourist numbers rose substantially (year-onyear increase of $37 \%$ or 150,000 visitors) to the island as a result of the children's television series Balamory. As such, one of her practical recommendations to the destination community was to plan, and invest in, marketing activity and be more proactive in taking control of the opportunity rather than leaving it to the vagaries of others. One of the biggest impediments to such an approach, however, is the unpredictability of what is, and what is not likely, to be popular with a mass rather than a niche audience. J.K. Rowling's Harry Potter is a classic case in question for although the global popularity of Harry Potter, Dumbledore and Voldermort is obvious now, it was not obvious to those who turned down the early manuscripts for publication!

6.2. From cultural/heritage tourism to international themed development

Although consistent with the earlier definition of literary destinations by Squire (1996, p.119) as 'places celebrated for literary depictions and/or connections with literary figures', it is perhaps stretching the point to imagine that Squire ever imagined multi-million dollar theme park developments around the world driven by children's favourite stories, myths, legends, cartoons and comic books as a form of literary tourism. Although not a catalyst for such developments, Harry Potter is once again seen to be of great significance here in influencing theme park design and development at Universal Studio's Islands of Adventure theme park alongside other literary figures such as Sinbad, Dr. Seuss, Spiderman and Captain America. Although one can perhaps question the depth of the visit experience at Universal's parks, especially when considering Watson's (2006) assertion that literary tourists' experiences are likely to be deeper when both the place of composition and that of the fictional setting coincide, their contribution to Orlando as one of the world's largest and most successful tourist destinations is second to none. In a similar vein, the potential for destination income generation from such developments is perhaps best demonstrated by Disney's $\$ 4$ billion acquisition of Marvel back in 2009. Although a long-standing literary "brand", the re-engagement of an entire generation in Marvel's iconic characters is testament to the marketing and branding potential of mass-market literary tourism. Interestingly, such scenarios are perhaps reflective of Herbert's (1995) initial thoughts on fact and fiction, real and imagined or real and metaphorical literary tourism opportunities. There is also a further debate to be had as to the migration toward more place-based opportunities; opportunities not traditionally associated with cultural interpretations of literary tourism.

6.3. Collaborative product and experiential development Although as stand-alone destinations, many literary places may lack the necessary "attraction" to entice tourists, collaborative approaches to destination marketing via tourist "routes", "trails" 
or "clusters" offer significant opportunity for new product and experiential destination development. The ability to connect destinations through literary figures has been evident recently with the likes of the DaVinci Code (London and Paris) and Harry Potter (numerous venues across the UK), while the publishing world is replete with innovative literary maps, books, apps, festivals and events to broaden the appeal of literature with a consequent knock-on benefit for tourism at related destinations. Consistent with the trend towards visiting a large range of literary tourism sites as postulated initially by Watson (2006), the collaborative opportunities for destinations are significant in broadening destination market appeal, countering seasonality and attracting new markets.

As with any collaborative venture, destination collaboration is no easy option (Fyall, Garrod, \& Wang, 2012) with the commitment of the salient stakeholder groups one of the earliest key tasks to be established (Garrod, Fyall, Leask, \& Reid, 2012). As with any destination, the challenge is to bring all the divergent components of the destination product together for the achievement of a common goal such as destination branding (see Morgan, Pritchard, \& Piggott, 2003). Where literary tourism is slightly different lies in the need to involve and proactively engage with often national and international publishers, authors, media organisations and film makers to achieve what in their eyes will often be viewed as outcomes (i.e. tourism) of secondary interest to their core business. A good example from the UK is the interactive literary map of the UK produced by the Guardian newspaper which was published in advance of a bank holiday weekend (Guardian, 2012). It is interesting to note that limited engagement was in evidence with the respective DMOs and destinations with the map produced as a means to sell more newspapers rather than deliver visitor numbers and bed nights. That said, the potential is considerable with literary tourism having much to learn from the more pre-active engagement evidenced recently between Disney and VisitScotland with regard to strategies designed to leverage maximum benefit from the film Brave for overseas visits to Scotland (BBC, 2012). As with film-induced tourism, it is important to ensure that such collaboration is consistent with the desired target markets of each stakeholder, is consistent with existing brands and is likely to be sustainable in the longer term. The latter is of particular note as the time and money invested into making such collaborative arrangements work are considerable.

In any literary tourism initiative, it is important to ensure that all stakeholders are in agreement with the quality of the literary tourism product and its ability to meet, if not exceed, the expectations of visitors. At the same time, authors and publishers will be keen to maintain ownership of the destination's touristic interpretation of their literary content and the degree to which it is commodified for the mass, rather than a niche, market. From the destination's perspective, the potential for product and experiential developments are considerable. For example, whether the products are core or complementary in nature, DMOs can leverage benefit from literary figures through the creation of literary festivals and events, themed one-day or time-specific (i.e. weekend, one month, two month, off-season) events and/or exhibitions at visitor attractions and late-night character nights or themed night-time events (see for example literaryfestivals.co.uk). There are also instances of destinations taking the initiative and creating "product placement" opportunities through the publishing of literary works which actively promote their destination through fiction where the destination represents the product (Hudson \& Ritchie, 2006, p.395). Disney's book series Kingdom Keepers by Ridley Pearson is a case in point where Disney's Magic Kingdom serves as the backdrop for a fantastical thriller in the first book with the sequel Disney at Dawn making an even more obvious statement of Disney's literary tourism intent (Pearson, 2005). Although collaboration may not be necessary for the latter example, where corporate control is more in evidence, collaboration across the wider destination of Orlando is critical if cocreation is to take place and deliver memorable experiences. More broadly, if collaboration can be achieved effectively across the destination, or even between destinations, then literary-driven destination branding is the next logical step.

6.4. Destination branding

As introduced earlier in the paper, numerous destinations over 
the years have developed destination brands based on literary figures with "Dickens' London" one of the more recent iterations (Watson, 2006). As with all destinations, the challenge for any destination branding strategy is the need to develop a suitable "umbrella" approach to appease and excite multiple markets and multiple market segments which may be attracted by different literary figures. As such, many destinations such as Dublin, London or Edinburgh where literary connections are evident destinationwide, are likely to benefit from multiple niche literary branding strategies to attract different markets albeit under an allencompassing "umbrella" brand which projects its literary appeal.

The UK's "Great" campaign is a current example of such a strategy whereby Ian Fleming's James Bond is the key literary figure selected to personify the rugged, iconic, timeless and adventurous attractiveness of the destination to potential, and repeat, overseas visitors. Although attractive to the older market, most notably Zoomers (see Hudson, 2010) who seek nostalgia and a desire to be "forever young", Harry Potter undoubtedly is likely to record a bigger impact with Millenials (Gunelius, 2008; Jewell \& McKinnon, 2008).

Despite the power of branding to generate interest and ultimate visitation, non-media promotion is viewed as a more embedded approach with longer-term benefits to be derived from deeper emotional and experiential engagement; rather than the more passive involvement alluded to in previous sections. If destinations are able to facilitate deeper engagement among their visitors with their literary interests, and in turn enhance their sense of identity with the destination or "place", such symbolic meanings and images can be utilised for future, and more sustainable, destination branding strategies. This is consistent with the views of Watson and Saunders (2004) who stipulated that it is the reader who imbues their own vision of reality with the author's written words, and therefore it is also the reader who actually produces the place.

6.5 . Broader policy and wider local visitor management context For each of the above to be effective, it is imperative that those marketing and managing destinations are cognisant of the wider political and policy contexts for tourism generally and for the organisation of festivals and events more specifically. As identified by Connell (2005), visitors are likely to frequent destinations irrespective of the strategies adopted by the relevant DMOs; they have limited interest in the day-to-day management of destinations. Nevertheless, the need for destinations to have a clear vision for tourism is critical. Without clarity in and across the destination, as well as collective buy-in from destination stakeholders, the ability to respond quickly to sudden demand from literary tourists will be difficult to accommodate with consequent limited potential to integrate literary tourism fully into its wider tourism agenda.

The above alludes to the fact that although predicting shortterm trends may not be too problematic, forecasting further into the future is beset with challenges, none more so than the increasing fickleness of markets generally and the difficulty inherent in managing unpredictable levels of demand. This impacts directly on the destination's ability to accommodate visitors when they do arrive, with carrying capacity and infrastructure more often than not in place for tourism markets other than literary tourists. Managing visitor impacts has been well documented in the literature (see for example Garrod, Fyall \& Leask, 2002), although there remains scope for further studies that explore the sudden emergence of literary-related product features and interpretation on non-tourism traffic; the case of Harry Potter interpretation at King's Cross Railway Station in London a very topical example in view of the many thousands of commuters who pass through this transportation hub every day. As with many of the strategies discussed throughout this paper, the ability to intertwine book or literary figures with newsworthy items, festivals and events, and existing destination products and experiences, will facilitate the ease with which additional visitor numbers can be accommodated and the management of unpredictable demand driven by literary tourism. With the additional power of local residents as attractors for inbound tourism and the generation of positive word of mouth of their local literary endowments local residents also represent a viable, and most likely significant, market for literary tourism. 


\section{Conclusion}

As mentioned by Connell (2005) in the context of film tourism, even if there is no intention to create a literary tourism destination, visitors will come anyway to "consume" their place. Literary tourism has grown into a commercially-significant phenomenon, which is evident despite the lack of statistical evidence on this particular type of tourism. It is suggested that places' connections to authors or literature be used to promote destinations more proactively, yet literary tourism remains under-researched in the academic world. To underpin the strategies used to develop and market a literary site for tourism, it is important to understand visitors' needs. Research in the field suggests that literary tourists are more purposeful and specific with regards to their reasons for visiting a literary site (Herbert, 1995). But even when visitors' needs are known to the developer of the literary place, there is still no guarantee that messages are read and interpreted in the intended way by visitors, as literary places are socially constructed (Herbert, 2001). Literary tourism is to a great extent about the interaction of "real and imagined" worlds and as such is a mixture of "fact and fiction", the "real and the metaphorical" (Herbert, 1995). The fundamental question in this context remains that posed by Robinson \& Picard, 2004, p. 40): 'what is there contained between the covers of a book that can induce, inspire, motivate and transform readers into tourists?' Herbert (2001) argues that each visitor has their own chemistry with a place, and associated characters and events, be they real-life or fictional. The purpose of future research should be to ascertain what motivates and satisfies literary tourists so as to best develop appropriate development and marketing strategies for destinations to prosper more fully. In view of the discussion throughout this paper, a number of new avenues for research appear viable.

The first avenue relates to geography and investigations into the potential and practices of literary tourism beyond Europe and North America. Although literary tourism is evident in other countries, research is limited while to date UNESCO has yet to nominate a creative city beyond Europe and North America. This is a little surprising especially in view of the city of Zhongdian in China's Yunnan province as the fictional Shangri la to attract western tourists! In addition to potential and practice, the people (or market) factor needs to be researched further with a suitable starting point being the comparison of Western and Asian literary tourism motivations, needs, experiences and trends.

A second research avenue relates to gender in that although most studies assume a female bias, the migration from a niche to a mass product is in part being driven, one suspects, by males. One area where males do, one suspects, influence literary tourism more profoundly is in the area of non-fiction adventure travel and biographies, more often than not of a sporting bias. Far more research is required here as is there also with the avenue of "living" literary tourism as evidenced in the paper through the example of Ian Rankin in Edinburgh, Scotland. One of the challenges for all authors who consider contributing to literary tourism development is that of copyright and legal protection; an avenue that is highly sensitive as evidenced by the very careful management of the Harry Potter brand by Universal and his creator JK Rowling. An additional avenue for research is that of film tourism, a significant promoter of literary tourism, and its future contribution to place-shaping and image-making.

Finally, as with many destination branding or marketing opportunities, collaboration is vital with collaborative leadership skills critical in bringing all the divergent components of the campaign together for the achievement of a common goal. As introduced in the paper, where literary tourism is slightly different lies in the need to involve and proactively engage with often national and international publishers, authors, media organisations and film makers to achieve what in their eyes will often be viewed as outcomes (i.e. tourism) of secondary interest to their core business. That said, the potential is considerable while it is critical to ensure that collaboration is consistent with the desired target markets of each stakeholder, is consistent with existing brands and is likely to be sustainable in the longer term.

References 
Barke, M. (2002). "Inside" and "Outside" writings on Spain: Their relationship to Spanish tourism. In: H.C. Andersen, \& M. Robinson (Eds.), Literature and

tourism - Reading and writing tourism texts. London: Continuum.

BBC. (2012). Disney/Pixar link up with VisitScotland a tourism 'first'. 〈http://www. bbc.co.uk/news/uk-scotland-highlands-islands-17220359) Accessed 13.06.13. Beeton, S. (2005). Film-induced tourism. Clevedon: Channel View Publications. Booth, A. (2004). Homes and haunts and the real right place of Henry James. In M. Robinson, \& D. Picard (Eds.), Conference proceedings tourism and literature: travel, imagination and myth, 22-26 July 2004, Harrogate. CD-ROM. Sheffield: Centre for Tourism and Cultural Change.

Bourdieu, P. (1986). The forms of capital. In: J. Richardson (Ed.), Handbook of theory and research for the sociology of education. Greenwood: Westport.

Bradbury, M. (1996). The atlas of literature. New York: Stewart, Tabori \& Chang.

Brito, L. M. (2004). Tourism promotion and literary itineraries. In M. Robinson, \& D.

Picard (Eds.), Conference proceedings tourism and literature: travel, imagination and myth, 22-26 July 2004, Harrogate. CD-ROM. Sheffield: Centre for Tourism and Cultural Change.

Busby, G. (2004). Representations of Cornwall in fiction: the influence on tourism. In M. Robinson, \& D. Picard, (Eds.) Conference proceedings tourism and literature: travel, imagination and myth, 22-26 July 2004, Harrogate. CD-ROM. Sheffield: Centre for Tourism and Cultural Change.

Busby, G., Brunt, P., \& Lund, J. (2003). In Agatha Christie country: Resident

Busby, G., Brunt, P., \& Lund, J. (2003). In Agatha Christie country: Resident

Busby, G., George, J. (2004).The tailor of Gloucester: Potter meets Potter - Literary tourism in a Cathedral City. In M. Robinson, \& D. Picard (Eds.), Conference proceedings tourism and literature: travel, imagination and myth, 22-26 July 2004, Harrogate. CD-ROM. Sheffield: Centre for Tourism and Cultural Change. Busby, G., Hambly, Z. (2000). Literary tourism and the Daphne du Maurier Festival. In P. Payton (Ed.), Cornish studies 8 (pp. 197-212). Exeter: University of Exeter Press. Available from: 〈http://plymouth.academia.edu/GrahamBusby/Papers/ 10090/Literary_Tourism_and_the_Daphne_du_Maurier_Festival). Accessed 10.03.11.

Busby, G., \& Klug, J. (2001). Movie-induced tourism: The challenge of measurement and other issues. Journal of Vacation Marketing, 7(4), 316-332.

Busby, G., \& O'Neill, K. (2006). Cephallonia and Captain Corelli's Mandolin: The influence of literature and film on British visitors. Acta Turistica, 18(1), 30-51.

Butler, R. (1986). Literature as an influence in shaping the image of tourist destinations: A review and case study. In J. Marsh (Ed.) Canadian studies of parks, recreation and foreign lands (pp. 111-132). Occasional paper no. 11, Peterborough, Department of Geography, Trent University.

Connell, J. (2005). Toddlers, tourism and tobermory: Destination marketing issues and television-induced tourism. Tourism Management, 26, 763-776.

Cosma, S., Pop, C., \& Negrusa, A. (2007). Should dracula myth be a brand to promote romania as a tourist destination? Interdisciplinary Management Research, 3 , 39-56.

Creative Media Publishing (2011). The official guide to Daphne Du Maurier. Paignton: Creative Media Publishing.

Daily Mail (2013). 〈http://www.dailymail.co.uk/news/article-2427855/Tourism-fi gures-jump-Downton-Abbey-Harry-Potter-weave-magic-visitors.html)

Accessed 04.12.13.

Devon History Society, (2010). The ochidore and Westward Ho!. Available from

〈http://www.devonhistorysociety.org.uk/2010/06/ochidore-and-west ward-ho.html Accessed 12.10.13.

Echtner, C. \& Ritchie, J. R. B. (2003). The meaning and measurement of destination image. The Journal of Tourism Studies, 14(1), 2003.

Eco, U. (1986). Travels in hyperreality. Orlando, Florida: Harcourt Inc.

Economist (2009). 〈http://www.economist.com/node/15108711〉 Accessed 04.12.13. Fawcett, C., \& McCormack, P. (2001). Guarding authenticity at literary tourism sites. Annals of Tourism Research, 28(3), 686-704.

Fyall, A., Garrod, B., \& Wang, Y. (2012). Destination collaboration: A critical review of theoretical approaches to a multi-dimensional phenomenon. Journal of

Destination Marketing \& Management, 1(1-2), 10-26.

Destination Marketing \& Management, $1(1-2), 10-26$. Garrod, B., Fyall, A., \& Leask, A. (2002). Scottish visitor attractions: Managing visitor impacts. Tourism Management, 23(3), 265-279.

Garrod, B., Fyall, A., Leask, A., \& Reid, E. (2012). Engaging residents as stakeholders of the visitor attraction. Tourism Management, 33(5), 1159-1173.

Goodreads.com (2013). A classic from the New York Times bestselling author of one summer. Available from: 〈https://www.goodreads.com/book/show/24.In a

Sunburned_Country\# $\rangle$ Accessed 25.10.13.

Graham, J., Gilbert, B., Minton, A., Perryman, M., Poynter, G., \& Westall, C. (2013) Revisiting the olympic legacy. Soundings, 53(11), 82-92.

Guardian (2012). The Guardian launches an interactive literary map of the UK.

〈http://www.guardian.co.uk/books/booksblog/2012/jun/01/interactive-literar y-map-uk-guardian $\rangle$ Accessed 13.06.13.

Gunelius, S. (2008). Harry Potter: The story of a global business phenomenon. Basingstoke: Palgrave Macmillan.

Hahn, D., \& Robins, N. (2008). The Oxford guide to literary Britain and Ireland. London: Oxford University Press.

Hay Festival 2012 Report, (2012). Hay Festival Wales. 〈https://www.hayfestival. com/portal/documents/HayFestival2012Report.pdf) Accessed 04.12.13.

Herbert, D. (2001). Literary places, tourism and the heritage experience. Annals of Tourism Research, 28(2), 312-333.

Herbert, D. T. (1995). Heritage, tourism and society. London: Mansell Publishing. Herbert, D. T. (1996). Artistic and literary places in France as tourist attractions. Tourism Management, 17, 77-85.

Hudson, S. (2010). Wooing zoomers: Marketing to the mature traveller. Marketing Intelligence and Planning 28(4), 444-461.

Hudson, S., \& Brent Ritchie, J. R. (2006). Promoting destinations via film tourism: An empirical identification of supporting marketing initiatives. Journal of Travel Research, 44(1), 387-396.

Hughes, E. (1995). Authenticity in tourism. Annals of Tourism Research, 22(4), 781-803. 
Investopedia (2013). E-Books Vs. Print Books. Available from: 〈http://www.investope dia.com/financial-edge/0812/e-books-vs.-print-books.aspx> Accessed 20.10.13.

Jewell, B., \& McKinnon, S. (2008). Movie tourism: A new form of cultural landscape. Journal of Travel and Tourism Marketing, 24(2-3), 153-162.

Lee, Y., \& Weaver, D. (2012). The tourism area life cycle in Kim Yujeong Literary

Village, Korea. Asia Pacific Journal of Tourism Research, 19(2), 181-198.

Macleod, N., Hayes, D., \& Slater, A. (2009). Reading the landscape: The development of a typology of literary trails that incorporate an experiential design perspective.

Journal of Hospitality Marketing and Management, 18(2-3), 154-172.

Mintel (2010). Cultural and heritage tourism -international - May 2010. London:

Mintel International Group.

Mintel (2011). Literary tourism - international - September (p. 2011) London: Mintel International Group.

Morgan, N., Pritchard, A., \& Piggott, R. (2003). Destination branding and the role of the stakeholders: The case of New Zealand. Journal of Vacation Marketing, 9(3),

285-299.

Müller, D. K. (2006). Unplanned development of literary tourism in two municipalities in rural Sweden. Scandinavian Journal of Hospitality and Tourism, 6(3),

214-228.

Muresan, A., \& Smith, K. A. (1998). Dracula's castle in Transylvania: Conflicting heritage marketing strategies. International Journal of Heritage Studies, 4(2), 73-85.

Orion publishing group (2011). Ian Rankin's Edinburgh app now available for Android phones. Available from: 〈http://www.ianrankin.net/pages/news/index.asp? NewsID=55〉 Accessed 28.10.13.

Ousby, I. (1999). Blue guide to literary Britain and Ireland. London. A\&C Black. Pearson, R. (2005). Kingdom keepers: Disney after dark. New York: Disney Hyperion Books.

Philips, D. (1999). Narrativised spaces: The functions of story in the theme park. In: D. Crouch (Ed.), Leisure/tourism geographies: Practices and geographical knowledge (pp. 91-102). London: Routledge.

Pike, S., \& Ryan, C. (2004). Destination positioning analysis through a comparison of cognitive, affective, and conative perceptions. Journal of Travel Research, 42, 333-342.

Pocock, D. (1982).Writers who knew their places. The Geographical Magazine, 54(1), 40-43.

Pollard-Gott, L. (2009). The Fictional 100 - Ranking the most influential characters in world literature and legend. Bloomington: iUniverse.

Random House (2013). Author: Bill Bryson. Available from: 〈http://www.random

house.co.uk/authors/bill-bryson〉 Accessed 26.10.13.

Reijnders, S. (2011). Stalking the count: Dracula, fandom and tourism. Annals of

Tourism Research, 38(1), 231-248.

Robertson, J. P., \& Radford, L. A. (2009). The private uses of quiet grandeur: A

meditation on literary pilgrimage. Changing English, 16(2), 203-209.

Robinson, M. (2002). Between and beyond the page: Literature - tourism relationships. In: H.-C. Andersen, \& M. Robinson (Eds.), Literature and tourism - Reading

and Writing Tourism Texts. London: Continuum.

Robinson, M., Picard, D. (2004). Conference proceedings tourism and literature: travel, imagination and myth, 22-26 July, Harrogate. CD-ROM. Sheffield: Centre for

Tourism and Cultural Change.

Seaton, T. (1999). Book towns as tourism developments in peripheral areas.

International Journal of Tourism Research, 1, 389-399.

Smith, A. K. (2003). Literary enthusiasts as visitors and volunteers. International

Journal of Tourism Research, 5(2), 83-95.

Squire, S. J. (1994). The cultural values of literary tourism. Annals of Tourism Research, 21, 103-120.

Squire, S. J. (1996). Literary tourism and sustainable tourism: Promoting 'Anne of

Green Gables' in Prince Edward Island. Journal of Sustainable Tourism, 4(3),

$119-134$.

Struthers, J., \& Coe, J. (2005). Literary Britain and Ireland: a guide to the places that inspired poets, playwrights and novelists. London: New Holland.

Tetley, S., \& Bramwell, B. (2002). Tourists and the cultural construction of Haworth's literary landscape. In: H.-C. Andersen, \& M. Robinson (Eds.), Literature and tourism - Reading and writing tourism texts. London: Continuum.

Tourism New Zealand (2013). Fast Facts. Available from: 〈http://www.tourismnew zealand.com/sector-marketing/film-tourism/fast-facts/) Accessed 27.10.13.

UNESCO (2013). Creative Cities Network. Available from: 〈http://www.unesco.org new/en/culture/themes/creativity/creative-cities-network/> Accessed 28.10.13.

VisitBritain, (2010). Culture and heritage. Available from:〈http://www.visitbritain.org insightsandstatistics/topics/cultureheritage/heritage.aspx $>$ Accessed 07.10.11.

VisitCornwall (2011). Daphne du Maurier. Available from: 〈http://www.fowey.co. uk/local-information/daphne-du-maurier〉 Accessed 22.03.11.

VisitKorea (2013). Kim You-jeong House of Literature (Sille Village). Available from:

〈http://www.visitkorea.or.kr/enu/SI/SI_EN_3_1_1_1.jsp?cid=628291〉

Accessed 28.10.13.

Watson, C., \& Saunders, R. (2004). The production of literary landscapes. In M.

Robinson, \& D. Picard (Eds.), Conference proceedings tourism and literature:

travel, imagination and myth, 22-26 July 2004, Harrogate. CD-ROM. Sheffield:

Centre for Tourism and Cultural Change.

Watson, N. J. (2006). The literary tourist. Basingstoke: Palgrave Macmillan. 